\title{
Growth responses to planting density and management intensity in loblolly pine plantations in the southeastern USA Lower Coastal Plain
}

\author{
Dehai Zhao $\cdot$ Michael Kane $\cdot$ Bruce E. Borders
}

Received: 3 May 2010 / Accepted: 12 October 2010/Published online: 31 March 2011

(C) INRA and Springer Science+Business Media B.V. 2011

\begin{abstract}
- Background A culture/density study was established in 1995 in the Lower Coastal Plain of the southeastern USA to evaluate the effects of intensive silviculture and current operational practices on the growth and yield of loblolly pine plantations across a wide range of planting densities (741-4,448 trees/ha). The operational regime consisted of bedding and herbicide application in site preparation and fertilizer applications at planting and in the eighth and 12th growing seasons. The intensive management regime had additional complete competition control, tip moths control, and more repeated fertilization treatments.

- Methods The data from 14 locations from this split-plot experiment design with repeated measurements were analyzed with a mixed-effects model approach in terms of average $\mathrm{DBH}$, average height, average dominant height, survival, stand basal area, and stand volume.

- Results In the first few years after planting, there were no significant effects of management intensity and planting density. In later years, both management intensity and planting density significantly impacted response variables, and their interaction was only significant for average diameter at breast height (DBH). Responses to intensive management in DBH were greatest at the lowest planting densities. Intensive management resulted in larger average $\mathrm{DBH}$, average height, dominant height, stand basal area, and volume. Intensively managed plots had more mortality at age 12 . There were negative average $\mathrm{DBH}$, average
\end{abstract}

Handling Editor: Reinhart Ceulemans

D. Zhao $(\square) \cdot$ M. Kane $\cdot$ B. E. Borders

Warnell School of Forestry and Natural Resources,

University of Georgia,

Athens, GA 30602, USA

e-mail: dzhao@warnell.uga.edu height, dominant height, and survival responses but positive stand basal area and volume responses to increasing planting density. However, there were no significant differences for planting densities above 2,224 trees/ha.

- Conclusions The results demonstrate that both management intensity and planting density significantly affect loblolly pine productivity in the Lower Coastal Plain, and their effects are additive in nature due to the general lack of interactions.

Keywords Intensive forest management . Vegetation control $\cdot$ Fertilization $\cdot$ Split-plot with repeated measurements

\section{Introduction}

Loblolly pine (Pinus taeda L.) is the most common and commercially important species in the southeastern USA. Industrial forest landowners in this area have experienced an increasing pressure to maximize the volume per hectare production from loblolly pine plantations due to the increasing demand for wood products from a decreasing wood production land base. Intensive silvicultural treatments including deployment of genetically improved seedlings, site preparation, competing vegetation control, and fertilization are commonly used to enhance productivity and reduce rotation length in loblolly pine plantations (Martin and Jokela 2004). Several silvicultural studies have reported significant gains in pine growth and yield due to tree improvement and more intensive management practices (e.g., Zutter and Miller 1998; Shiver and Martin 2002; Martin and Shiver 2002; Miller et al. 2003; Nilsson and Allen 2003; Land et al. 2004; Borders et al. 2004; Zhao et al. 2008a; Zhao et al. 2009a, b). 
The choice of planting density is one of the most important decisions that must be made at the time of plantation establishment. There are numerous experimental spacing studies that show the influence of planting density on loblolly pine tree growth and stand development. Pienaar and Shiver (1993) reported that, for loblolly pine at age 8 years, there was a clear trend of declining average diameter at breast height $(\mathrm{DBH})$ as the planting density increased from 494 trees/ha to 2,741 trees/ha and no significant differences in average height for planting densities of 988 to 2,471 trees/ha. They also found that stand basal area and stem volume increased as the planting density increased, but the increase was not significant in basal area above 1,977 trees/ha and in total stem volume above 1,483 trees/ha. Harms et al. (2000) observed that, for loblolly pine, average height and average DBH at lower planting densities were consistently greater than at higher planting densities and stand basal area and volume increased with increasing planting density. Sharma et al. (2002) found that planting density had a significant effect on average height after age 9 and on average DBH across all ages over the 16-year study period.

The studies mentioned above were designed to investigate either silvicultural treatment effect or planting density effect alone. In some other studies, the effect of a specific silvicultural treatment has been evaluated along with planting density effect, such as herbaceous vegetation control and planting density effects (Quicke et al. 1999), genetic and spacing effects (Land et al. 2004), repeated early fertilization and planting density effects (Carlson et al. 2009). Unfortunately, few studies were designed to investigate the effects of management regime (a series of treatments) and planting density and their interactions in the same study. There is little understanding of the relationships between management regimes and establishment densities.

To fill this knowledge gap, the Plantation Management Research Cooperative at the University of Georgia initiated a loblolly pine culture/density study in the lower coastal plain of the southeastern USA to evaluate the effects of intensive silviculture and current operational practices on the growth and yield of loblolly pine plantations across a wide range of planting densities. The objectives of the study were to (1) quantify the growth response of loblolly pine to different cultural intensities and planting densities in the Lower Coastal Plain, (2) determine whether the effects of cultural intensity and planting density interact, and (3) determine temporal patterns in possible planting density and management intensity effects. We report on the responses over the first 12 years after planting.

\section{Materials and methods}

\subsection{Study description}

The lower coastal plain culture/density study was established in $1995 / 1996$. Seventeen installations were established in the Lower Coastal Plain of Georgia, Florida, and South Carolina (Fig. 1), on either Spodosols or Ultisols. Study sites were typically on somewhat poorly to poorly drained soils of relatively low fertility often with natural vegetation dominated by waxy-leaf species such as gallery (Ilex glabra) or palmetto (Serenoa repens). Site preparation and subsequent silvicultural regimes were designed to represent two levels of management intensity: operational and intensive culture (Table 1). Within each level of management intensity, six loblolly pine subplots with densities of $741,1,483,2,224,2,965,3,706$, and 4,448 trees/ha were planted. At each installation (site), there was a random allocation of management intensities to main plots. Within a management intensity level, the density subplots were randomly assigned. The planting stock used for all installations was one, first-generation, open-pollinated family that was widely planted commercially in the region. Seedlings were grown in one nursery and planted as bare-rooted 1-0 stock. To ensure the targeted initial density, each planting spot was double-planted and reduced to a single surviving seedling after the first growing season.

Treatment plots were comprised of an interior measurement plot that ranged from 80 to 184 trees per plot, for the 741 and 4,448 trees/ha densities, respectively, and a surrounding 7.3-m-wide buffer area. Tree measurements were taken after from 2 to 12 growing seasons at 2-year intervals. At each measurement, all trees that were at least $1.4 \mathrm{~m}$ tall were measured for DBH. After the fourth growing season, every other tree was tagged and measured for total height $(H)$. The total height of untagged trees was estimated from the model $\ln (H)=b_{0}+b_{1} \mathrm{DBH}^{-1}$ separately fitted for height-measured trees in each plot at each measurement age. A tree was considered a dominant tree if it was in the upper $50 \%$ of DBH on the plot. Total outside bark volumes were calculated using the individual tree volume equation developed by Pienaar et al. (1987).

One installation was heavily damaged from disease at age 6 and two installations were lost from landowner harvesting at age 10 . By age 12 years, 14 installations remain. Data from these 14 viable installations were used for the analysis reported here.

\subsection{Statistical analysis}

The arrangement of cultural treatments and planting densities results in a split-plot design. The main plots are cultural treatments and the subplots are planting densities. 


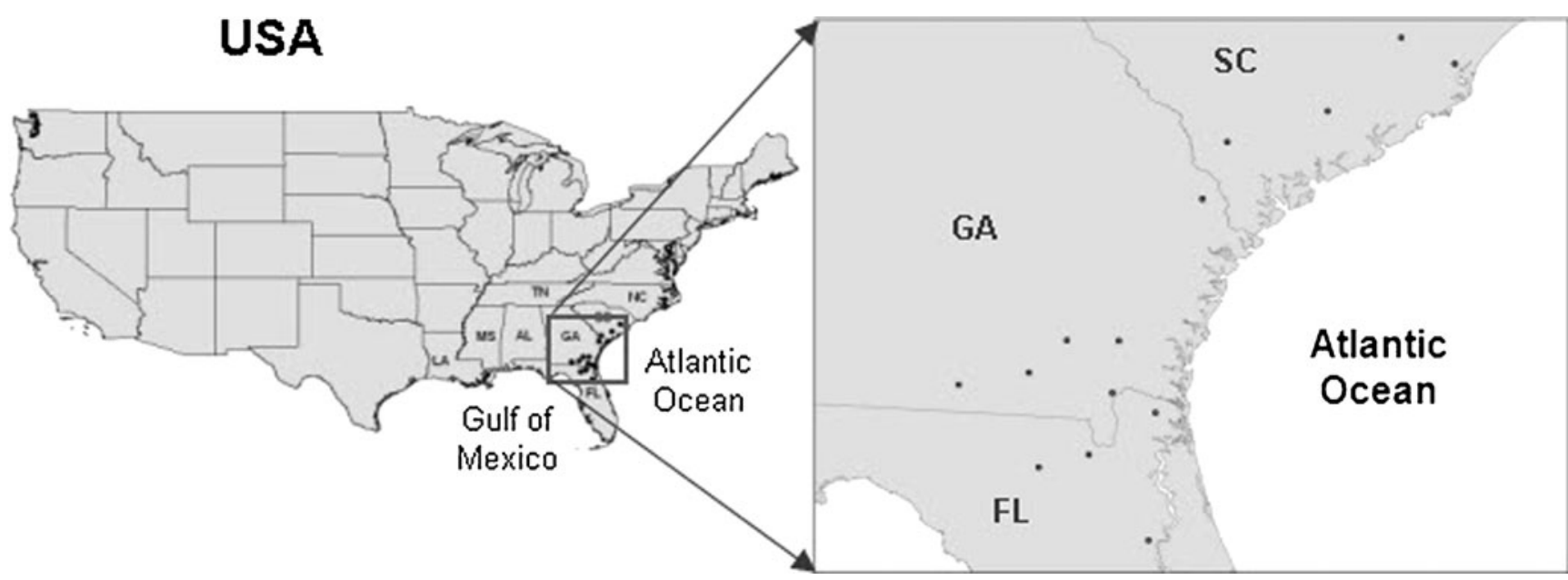

Fig. 1 General locations of the installations of the loblolly pine culture/density study

Furthermore, trees in each subplot were measured at 2, 4, 6, 8,10 , and 12 years after planting. Thus, the data are from a split-plot experiment with repeated measures. Since the replications or installations can be considered as a random sample of all possible locations, the replication factor must be considered as random. This results in a mixed model. The correlation structure of the repeated measurements within a subplot also needs to be estimated. Let $y_{i j k l}$ denote the value of response variable for the $i$ th level of management intensity, $j$ th level of planting density, $k$ th installation, and $l$ th time point. Then, the linear model is written as:

$$
\begin{aligned}
y_{i j k l}= & \mu+\alpha_{i}+\gamma_{k}+\delta_{i k}+\beta_{j}+(\alpha \beta)_{i j}+e_{i j k}+\tau_{l} \\
& +(\alpha \tau)_{i l}+(\beta \tau)_{j l}+(\alpha \beta \tau)_{i j l} \\
& +\varepsilon_{i j k l}(i=1,2 j=1, \ldots, 6 k=1, \ldots, 14 l=1, \ldots, 6)
\end{aligned}
$$

where

\section{$\mu \quad$ overall mean}

$\alpha_{i} \quad$ the effect of the $i$ th management intensity

$\gamma_{k}$ the random effect of replication (installation) with $\gamma_{k} \sim$ i.i.d.N $\left(0, \sigma_{r}^{2}\right)$

$\delta_{i k} \quad$ the random effect of the $i$ th management intensity in the $k$ th installation with $\delta_{i k} \sim$ i.i.d.N $\left(0, \sigma_{\delta}^{2}\right)$

$\beta_{j} \quad$ the effect of the $j$ th planting density

$(\alpha \beta)_{i j} \quad$ the interaction effect of the $i$ th management intensity with $j$ th planting density

$e_{i j k} \quad$ the random effect of the $j$ th subplot in the $i$ th whole plot of the $k$ th installation with $e_{i j k} \sim$ i.i.d. $N\left(0, \sigma_{e}^{2}\right)$

$\tau_{l} \quad$ the effect of the $l$ th time point

$(\alpha \tau)_{i l} \quad$ the interaction effect of the $i$ th management intensity with the lth time point

$(\beta \tau)_{j l} \quad$ the interaction effect of the $j$ th planting density with the $l$ th time point

$(\alpha \beta \tau)_{i j l}$ the interaction effect of the $i$ th management intensity with $j$ th planting density at the $l$ th time point

$\varepsilon_{i j k l} \quad$ the random effect of the $j$ th subplot in the $i$ th whole plot of the $k$ th installation at the $l$ th time point with $\varepsilon_{i j k l} \sim$ i.i.d. $\mathrm{N}(0 . \Sigma)$

and the random effects $\gamma_{k}, \delta_{i k}, e_{i j k}$, and $\varepsilon_{i j k l}$ are independent

\begin{tabular}{|c|c|}
\hline Operational regime & Intensive regime \\
\hline Bedding & Bedding \\
\hline \multirow[t]{2}{*}{ Fall banded chemical site preparation } & Fall broadcast chemical site preparation \\
\hline & Tip moth control \\
\hline Herbaceous weed control: 1st year banded & Repeated herbicide application to achieve complete vegetation control \\
\hline $\begin{array}{l}\text { Fertilization: at planting, } 561 \mathrm{~kg} \mathrm{ha}^{-1} \text { of } 10-10-10 \text {; before eighth } \\
\text { and 12th growth season, } 224 \mathrm{~kg} \mathrm{ha}^{-1} \mathrm{~N}+28 \mathrm{~kg} \mathrm{ha}^{-1} \mathrm{P}\end{array}$ & $\begin{array}{l}\text { Fertilization: at planting, } 561 \mathrm{~kg} \mathrm{ha}^{-1} \text { of } 10-10-10 \text {; spring third grow season, } \\
673 \mathrm{~kg} \mathrm{ha}^{-1} 10-10-10+\text { micronutrients }+131 \mathrm{~kg} \mathrm{ha}^{-1} \mathrm{NH}_{4} \mathrm{NO}_{3} \text {; spring } \\
\text { fourth grow season } 131 \mathrm{~kg} \mathrm{ha}^{-1} \mathrm{NH}_{4} \mathrm{NO}_{3} \text {; spring sixth grow season } 336 \mathrm{~kg} \\
\text { ha }^{-1} \mathrm{NH}_{4} \mathrm{NO}_{3} \text {; spring eighth, tenth, and } 12 \text { th grow season } 224 \mathrm{~kg} \mathrm{ha}^{-1} \mathrm{~N}+ \\
28 \mathrm{~kg} \mathrm{ha}^{-1} \mathrm{P}\end{array}$ \\
\hline
\end{tabular}
of each other.

Table 1 Silvicultural treatments for the loblolly pine culture/density study in the Lower Coastal Plain 
In order to make a proper inference across all sites, the presence of the random factor must be considered. All factors containing installation were considered random and were listed in the RANDOM statement; first-order autoregressive $\mathrm{AR}(1)$ as the covariance structure for the repeated measures was specified in the REPEATED statement in SAS ${ }^{\circledR}$ 's PROC MIXED (Littell et al. 2006).

With model (1), the hypotheses of no differences between management intensities, no differences among planting densities, and no interactions of management intensity with planting density, averaged over the period of ages 2-12 years, were tested. Simultaneously, whether the effects of planting density and management intensity and their interaction effects change over time or not was also tested in model (1). If they significantly changed over time, the differences between management intensities, the differences among planting densities, and the interactions of management intensity with planting density were examined using the pairwise comparisons with the Tukey method at each measurement age. The analyses were performed separately on the following response variables: average $\mathrm{DBH}$, average height, average dominant height, survival, stand basal area, and total stem volume. Survival percentages were transformed using an arcsine square-root transformation prior to analysis. All tests were conducted at the $\alpha=0.05$ level. Table 2 gives the significance level $(\operatorname{Pr}>F)$ from the tests of fixed effects.

\section{Results}

With regard to $\mathrm{DBH}$, there were significant effects of management intensity, planting density, and their interactions, and these effects did change over time (Table 2). Further analysis indicated that management intensity had a significant effect on average DBH development after age 4 . Effects of management intensity were calculated by averaging across all planting densities. Compared to operational management, the intensive management significantly increased average DBH by $45 \%(2.8 \mathrm{~cm}), 30 \%$ $(2.8 \mathrm{~cm}), 20 \%(2.3 \mathrm{~cm}), 14 \%(1.9 \mathrm{~cm})$, and $13 \%(1.9 \mathrm{~cm})$ at ages $4,6,8,10$, and 12 , respectively. Planting density had a significant effect on average DBH after age 4 with intensive management and after age 6 with operational management (Table 3). There was a clear trend of declining average DBHs as the planting density increases from 741 trees/ha to 4,448 trees/ha for both management intensities (Fig. 2). Although the intensively managed plots had larger average DBH than the operational plots at each of the planting densities, the DBH difference due to management intensity was larger at lower initial densities (Fig. 2). At age 12, the average DBH of intensively managed plots ranged from a low of $13.2 \mathrm{~cm}$ for 4,448 trees/ha planting density to a high of $24.1 \mathrm{~cm}$ for 741 trees/ha density, while the average DBH of the operational plots ranged from $11.9 \mathrm{~cm}$ for 4,448 trees/ha density to 20.8 for 741 trees/ha density. That is, compared to operational management, the intensive management increased average DBH by $16 \%(3.3 \mathrm{~cm})$ for 741 trees/ha density and $11 \%(1.3 \mathrm{~cm})$ for 4,448 trees/ha density.

Planting density and management intensity had significant effects on both average height and average dominant height (Table 2). The interaction between management intensity and planting density with regard to both average height and dominant height was not significant. The interactions between management intensity and age and between planting density and age were significant, indicating that trees planted at different densities or with different management regimes had different height growth rates over time (Figs. 3 and 4). Intensive management significantly increased both average height and average dominant height compared with the operational practice after age 4 (Table 4; Figs. 3 and 4). Intensive management significantly increased average height by $25 \%(1.2 \mathrm{~m}), 21 \%(1.7 \mathrm{~m}), 16 \%$ (1.7), $12 \%(1.6 \mathrm{~m})$, and $12 \%(1.7 \mathrm{~m})$ and significantly increased average dominant height by $21 \%(1.1 \mathrm{~m}), 18 \%$ $(1.5 \mathrm{~m}), 14 \%(1.6), 10 \%(1.4 \mathrm{~m})$, and $10 \%(1.6 \mathrm{~m})$ compared to operational management at ages $4,6,8,10$, and 12 , respectively. Planting density did not significantly affect average height or dominant height through age 6 (Table 4). Thereafter, there were significant differences in both average height and dominant height between the lowest and highest planting densities. Trees planted at higher stand densities (3,706 and 4,448 trees/ha) had significantly lower average height and average dominant height than trees planted at lower stand densities (741 and 1,483 trees/ha). There was a general trend toward a lower average height and lower average dominant height as planting density increases. Average height at age 12 ranged from $15.5 \mathrm{~m}$ for 4,448 trees/ha density to $17.2 \mathrm{~m}$ for 741 trees/ha density in intensively managed plots and from $13.9 \mathrm{~m}$ for 4,448 trees/ha to $15.5 \mathrm{~m}$ for 741 trees/ha density in operational plots. Dominant height at age 12 decreased from 17.7 to $16.6 \mathrm{~m}$ in intensively managed plots and from $16.2 \mathrm{~m}$ to $15.0 \mathrm{~m}$ in operational plots as the planting density increased from 741 to 4,448 trees/ha.

The overall effects of management intensity, planting density, and their interaction on survival percentages were not significant, but both management intensity by age and planting density by age interactions were significant (Table 2), indicating that the effects of management intensity and planting density on survival did change over time. In general, loblolly pine survived better on operational regime plots than on intensive regime plots (Fig. 5). The survival difference due to management intensity became significant at age 12 (Table 4). At age 12, trees on 
Table 2 Results of the split-plot with repeated-measures analysis conducted with PROC MIXED indicating the $p$-values of the main fixed effects and their fixed effect interactions for average DBH $(\mathrm{cm})$, average height $(\mathrm{HT}, \mathrm{m})$, average dominant height (HD, m), survival
(\%), stand basal area (BA, $\mathrm{m}^{2} / \mathrm{ha}$ ), and total stem volume (TVOB, $\mathrm{m}^{3} /$ ha) on the loblolly pine culture/density study in the Lower Coastal Plain

\begin{tabular}{|c|c|c|c|c|c|c|}
\hline \multirow[t]{2}{*}{ Source } & \multicolumn{6}{|l|}{$p$-value } \\
\hline & DBH & HT & $\mathrm{HD}$ & Survival $^{\mathrm{a}}$ & BA & TVOB \\
\hline Manage & $<0.001$ & $<0.001$ & $<0.001$ & 0.479 & $<0.001$ & $<0.001$ \\
\hline Planting density & $<0.001$ & $<0.001$ & $<0.001$ & 0.171 & $<0.001$ & $<0.001$ \\
\hline Manage $\times$ planting density & $<0.001$ & 0.763 & 0.813 & 0.368 & 0.360 & 0.670 \\
\hline Age & $<0.001$ & $<0.001$ & $<0.001$ & $<0.001$ & $<0.001$ & $<0.001$ \\
\hline Age $\times$ manage & $<0.001$ & $<0.001$ & $<0.001$ & $<0.001$ & $<0.001$ & $<0.001$ \\
\hline Age $\times$ planting density & $<0.001$ & $<0.001$ & $<0.001$ & $<0.001$ & $<0.001$ & $<0.001$ \\
\hline Age $\times$ manage $\times$ planting density & $<0.001$ & 0.997 & 0.978 & 0.811 & 0.182 & 0.437 \\
\hline
\end{tabular}

${ }^{a}$ Arcsine-square-root-transformed data were used in the analysis

operational treatment plots survived $9.3 \%$ better than those on intensively managed plots. There were no significant survival differences due to planting density through age 8 . At ages 10 and 12, however, planting density significantly impacted the survival rate. With a general trend toward lower survival as planting density increases (Fig. 5), significant survival differences occurred between the lowest and highest densities (741 vs. 4,448 tree/ha). Averaged across management intensities, survival at age 12 decreased from $88.9 \%$ for 741 trees/ha initial density to $73.5 \%$ for 4,448 trees/ha density. Higher-density, intensively managed plots experienced higher mortality than the lower-density, operational plots.

Both management intensity and planting density significantly affected basal area, while their interaction was not significant (Table 2). The significant interactions of management and age and planting density by age indicated that the effects of both management intensity and planting density changed over time (Table 5). Across all planting densities, compared to the operational regime, intensive management significantly increased the basal area by $91 \%$ (6.6 m/ $/ \mathrm{ha}), 58 \%\left(8.9 \mathrm{~m}^{2} / \mathrm{ha}\right), 36 \%\left(8.2 \mathrm{~m}^{2} / \mathrm{ha}\right), 19 \%(5.7$ $\left.\mathrm{m}^{2} / \mathrm{ha}\right)$, and $12 \%\left(4.0 \mathrm{~m}^{2} / \mathrm{ha}\right)$ at ages $4,6,8,10$, and 12 , respectively (Fig. 6). Planting density effect on stand basal area was significant from age 4 . Basal area increased with increasing density. While the general effects of management intensity and planting density have remained consistent over time, basal area growth rates during the period of ages 10 to 12 for high-density or high-managementintensity plots were slowing down relative to basal area growth rates for low-density or low-intensity plots, respectively. Basal area at age 12 ranged from $29.8 \mathrm{~m}^{2} /$ ha for 741 trees/ha density to $42.0 \mathrm{~m}^{2} /$ ha for 4,448 trees/ha density on the intensively managed plots and from $24.2 \mathrm{~m}^{2} /$ ha for 741 trees/ha to $39.3 \mathrm{~m}^{2} / \mathrm{ha}$ for 4,448 trees/ha on the operational plots.

Total stem volume had a similar trend as the trend for stand basal area. The effects of both management intensity
Table 3 Pairwise comparisons for average DBH among planting densities for each management regime by age
Within management intensities and ages, the same letter indicates no significant difference among planting densities $(p=0.05)$

\begin{tabular}{llllllll}
\hline Management & Density & Age 2 & Age 4 & Age 6 & Age 8 & Age 10 & Age 12 \\
\hline Intensive & 741 & $\mathrm{a}$ & $\mathrm{a}$ & $\mathrm{a}$ & $\mathrm{a}$ & $\mathrm{a}$ & $\mathrm{a}$ \\
& 1,483 & $\mathrm{a}$ & $\mathrm{ab}$ & $\mathrm{b}$ & $\mathrm{b}$ & $\mathrm{b}$ & $\mathrm{b}$ \\
& 2,224 & $\mathrm{a}$ & $\mathrm{bc}$ & $\mathrm{c}$ & $\mathrm{c}$ & $\mathrm{c}$ & $\mathrm{c}$ \\
& 2,965 & $\mathrm{a}$ & $\mathrm{cd}$ & $\mathrm{cd}$ & $\mathrm{cd}$ & $\mathrm{d}$ & $\mathrm{d}$ \\
& 3,706 & $\mathrm{a}$ & $\mathrm{cd}$ & $\mathrm{de}$ & $\mathrm{de}$ & $\mathrm{de}$ & $\mathrm{de}$ \\
& 4,448 & $\mathrm{a}$ & $\mathrm{d}$ & $\mathrm{e}$ & $\mathrm{e}$ & $\mathrm{e}$ & $\mathrm{e}$ \\
& 741 & $\mathrm{a}$ & $\mathrm{a}$ & $\mathrm{a}$ & $\mathrm{a}$ & $\mathrm{a}$ & $\mathrm{a}$ \\
& 1,483 & $\mathrm{a}$ & $\mathrm{a}$ & $\mathrm{b}$ & $\mathrm{b}$ & $\mathrm{b}$ & $\mathrm{b}$ \\
& 2,224 & $\mathrm{a}$ & $\mathrm{a}$ & $\mathrm{c}$ & $\mathrm{c}$ & $\mathrm{c}$ & $\mathrm{c}$ \\
& 2,965 & $\mathrm{a}$ & $\mathrm{a}$ & $\mathrm{cd}$ & $\mathrm{d}$ & $\mathrm{d}$ & $\mathrm{d}$ \\
& 3,706 & $\mathrm{a}$ & $\mathrm{a}$ & $\mathrm{de}$ & $\mathrm{d}$ & $\mathrm{de}$ & $\mathrm{de}$ \\
& 4,448 & $\mathrm{a}$ & $\mathrm{a}$ & $\mathrm{e}$ & $\mathrm{d}$ & $\mathrm{e}$ & $\mathrm{e}$ \\
\hline
\end{tabular}




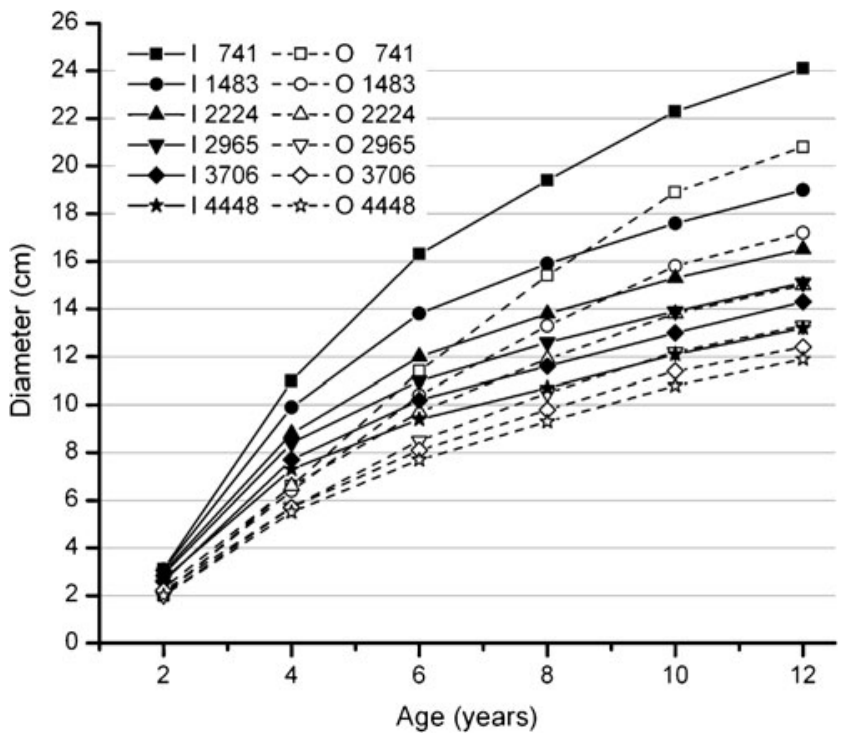

Fig. 2 Loblolly pine average DBH development over time by planting density (trees/ha) and management intensity ( $I$, intensive management; $O$, operational practice)

and planting density on volume were significant and changed over time, while their interaction was not significant (Table 2). The intensively managed plots had greater total stem volume than the operational plots across
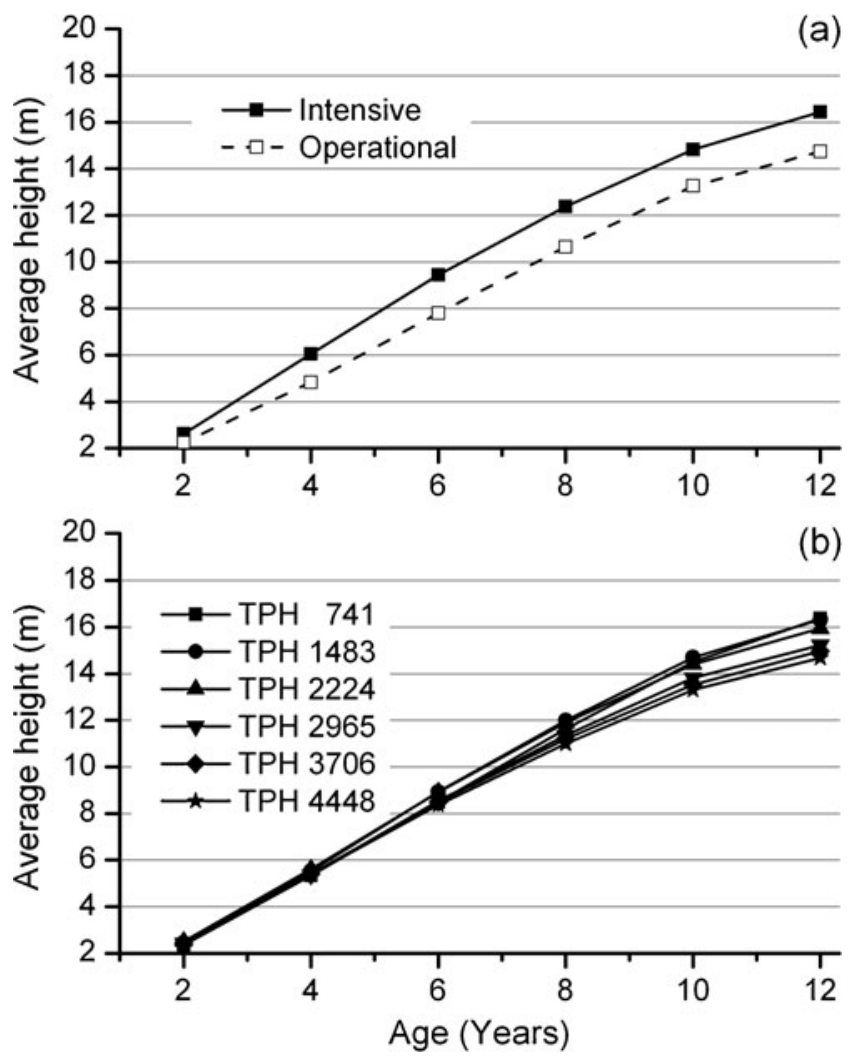

Fig. 3 Management intensity (a) and planting density (b) effects on average height of loblolly pine plantations
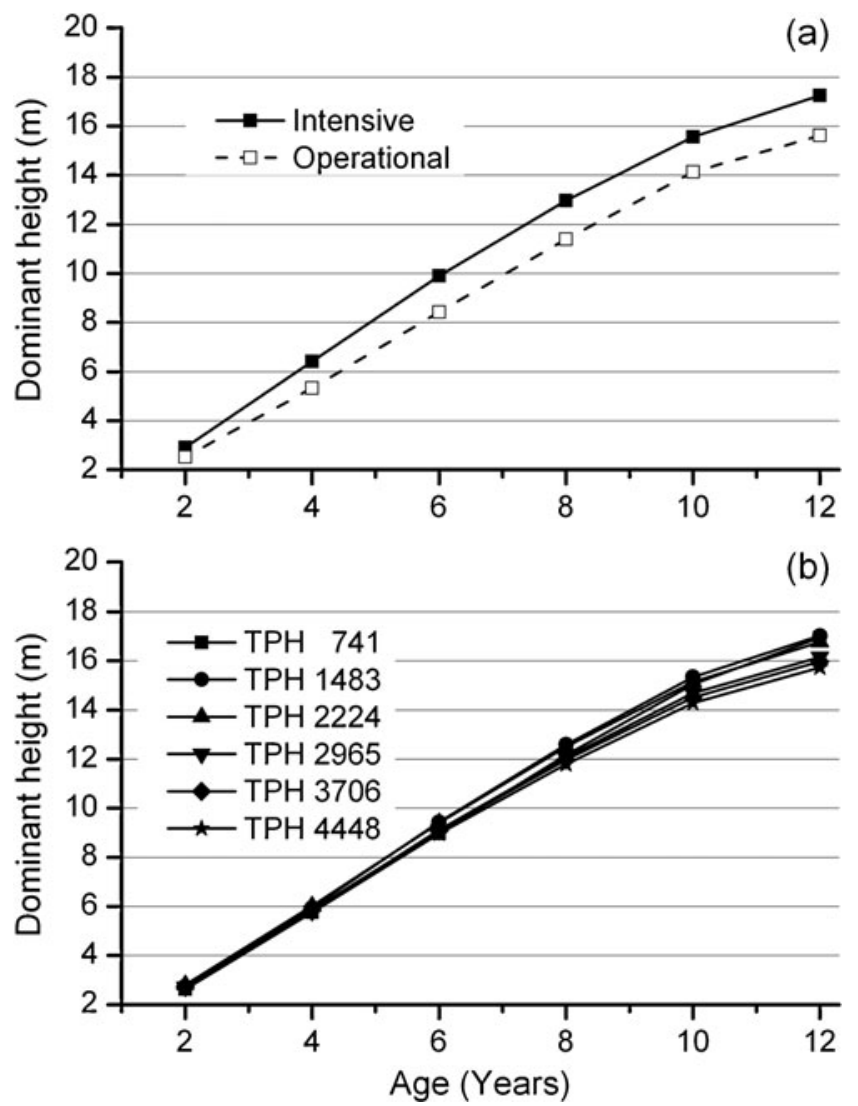

Fig. 4 Management intensity (a) and planting density (b) effects on average dominant height of loblolly pine plantations

all planting densities. Compared to the operational regime, intensive management significantly increased the total volume by $125 \%\left(20.3 \mathrm{~m}^{3} / \mathrm{ha}\right), 85 \%\left(47.5 \mathrm{~m}^{3} / \mathrm{ha}\right), 55 \%$ $\left(63.5 \mathrm{~m}^{3} / \mathrm{ha}\right), 32 \%\left(59.5 \mathrm{~m}^{3} / \mathrm{ha}\right)$, and $23 \%\left(54.6 \mathrm{~m}^{3} / \mathrm{ha}\right)$ at ages $4,6,8,10$, and 12, respectively (Fig. 7). Planting density had a significant effect on total volume after age 6 . In general, as the density increased, the volume increased as well. While the lowest-density (741 trees/ha) plots had produced a significantly lower volume than the other planting densities from age 6 , there was a little difference in volume for densities of 2,964 trees/ha and greater (Table 5; Fig. 6). On intensively managed plots, total volume at age 12 ranged from $228.2 \mathrm{~m}^{3} /$ ha for 741 trees/ha density to $317.7 \mathrm{~m}^{3} /$ ha for 4,448 trees/ha density. On operational plots, total volume at age 12 increased from $170.7 \mathrm{~m}^{3} /$ ha for 741 trees/ha density to $270.9 \mathrm{~m}^{3} / \mathrm{ha}$ for 4,448 trees/ha density.

\section{Discussion and conclusions}

In this study, the different treatments applied before the third growing season between the two management intensity levels were chemical site preparation and tip moth 
Table 4 Pairwise comparisons for average height, average dominant height, and survival among planting densities and between management regimes by age

\begin{tabular}{|c|c|c|c|c|c|c|c|}
\hline & & Age 2 & Age 4 & Age 6 & Age 8 & Age 10 & Age 12 \\
\hline \multicolumn{8}{|l|}{ Average height } \\
\hline \multirow[t]{2}{*}{ Management } & Intensive & $\mathrm{a}$ & $\mathrm{a}$ & $\mathrm{a}$ & $\mathrm{a}$ & $\mathrm{a}$ & $\mathrm{a}$ \\
\hline & Operational & $\mathrm{a}$ & $\mathrm{b}$ & $\mathrm{b}$ & $\mathrm{b}$ & $\mathrm{b}$ & $\mathrm{b}$ \\
\hline \multirow[t]{6}{*}{ Planting density } & 741 & $\mathrm{a}$ & $\mathrm{a}$ & $\mathrm{a}$ & $\mathrm{a}$ & $\mathrm{a}$ & $\mathrm{a}$ \\
\hline & 1,483 & $\mathrm{a}$ & $\mathrm{a}$ & $\mathrm{a}$ & $\mathrm{a}$ & $\mathrm{a}$ & $\mathrm{a}$ \\
\hline & 2,224 & $\mathrm{a}$ & $\mathrm{a}$ & $\mathrm{a}$ & $\mathrm{a}$ & $\mathrm{ab}$ & $\mathrm{a}$ \\
\hline & 2,965 & $\mathrm{a}$ & $\mathrm{a}$ & $\mathrm{a}$ & $a b$ & $\mathrm{bc}$ & $\mathrm{b}$ \\
\hline & 3,706 & $\mathrm{a}$ & $\mathrm{a}$ & $\mathrm{a}$ & $\mathrm{b}$ & $\mathrm{c}$ & $\mathrm{b}$ \\
\hline & 4,448 & $\mathrm{a}$ & $\mathrm{a}$ & $\mathrm{a}$ & $\mathrm{b}$ & $\mathrm{c}$ & $\mathrm{b}$ \\
\hline \multicolumn{8}{|l|}{ Dominant height } \\
\hline \multirow[t]{2}{*}{ Management } & Intensive & $\mathrm{a}$ & $\mathrm{a}$ & $\mathrm{a}$ & $\mathrm{a}$ & $\mathrm{a}$ & a \\
\hline & Operational & $\mathrm{a}$ & $\mathrm{b}$ & $\mathrm{b}$ & $\mathrm{b}$ & $\mathrm{b}$ & $\mathrm{b}$ \\
\hline \multirow[t]{6}{*}{ Planting density } & 741 & $\mathrm{a}$ & $\mathrm{a}$ & $\mathrm{a}$ & $\mathrm{a}$ & $\mathrm{a}$ & $\mathrm{a}$ \\
\hline & 1,483 & $\mathrm{a}$ & $\mathrm{a}$ & $\mathrm{a}$ & $\mathrm{a}$ & $\mathrm{a}$ & $\mathrm{a}$ \\
\hline & 2,224 & $\mathrm{a}$ & $\mathrm{a}$ & $\mathrm{a}$ & $a b$ & $\mathrm{a}$ & $\mathrm{ab}$ \\
\hline & 2,965 & $\mathrm{a}$ & $\mathrm{a}$ & $\mathrm{a}$ & $\mathrm{ab}$ & $a b$ & $\mathrm{bc}$ \\
\hline & 3,706 & $\mathrm{a}$ & $\mathrm{a}$ & $\mathrm{a}$ & $\mathrm{b}$ & $\mathrm{b}$ & $\mathrm{c}$ \\
\hline & 4,448 & $\mathrm{a}$ & $\mathrm{a}$ & $\mathrm{a}$ & $\mathrm{b}$ & $\mathrm{b}$ & $\mathrm{c}$ \\
\hline \multicolumn{8}{|l|}{ Survival } \\
\hline \multirow[t]{2}{*}{ Management } & Intensive & $\mathrm{a}$ & $\mathrm{a}$ & $\mathrm{a}$ & $\mathrm{a}$ & $\mathrm{a}$ & $\mathrm{a}$ \\
\hline & Operational & $\mathrm{a}$ & $\mathrm{a}$ & $\mathrm{a}$ & $\mathrm{a}$ & $\mathrm{a}$ & $\mathrm{b}$ \\
\hline \multirow[t]{6}{*}{ Planting density } & 741 & $\mathrm{a}$ & $\mathrm{a}$ & $\mathrm{a}$ & $\mathrm{a}$ & $\mathrm{a}$ & $\mathrm{a}$ \\
\hline & 1,483 & $\mathrm{a}$ & $\mathrm{a}$ & $\mathrm{a}$ & $\mathrm{a}$ & $a b$ & $\mathrm{ab}$ \\
\hline & 2,224 & $\mathrm{a}$ & $\mathrm{a}$ & $\mathrm{a}$ & $\mathrm{a}$ & $a b$ & $\mathrm{ac}$ \\
\hline & 2,965 & $\mathrm{a}$ & $\mathrm{a}$ & $\mathrm{a}$ & $\mathrm{a}$ & $a b$ & $\mathrm{ac}$ \\
\hline & 3,706 & $\mathrm{a}$ & $\mathrm{a}$ & a & $\mathrm{a}$ & $\mathrm{ab}$ & $\mathrm{bc}$ \\
\hline & 4,448 & $\mathrm{a}$ & $\mathrm{a}$ & $\mathrm{a}$ & $\mathrm{a}$ & $\mathrm{b}$ & $\mathrm{c}$ \\
\hline
\end{tabular}

$\overline{\text { Within ages, the same letter among planting densities or the same letter between management regimes indicates no significant difference }(p=0.05)}$

control (Table 2). That is, the operational regime consisted of a fall herbicide treatment applied in $1.5-\mathrm{m}$ band over the rows and no subsequent tip moth control, while the intensive regime included a fall broadcast herbicide application and subsequent tip moth control. Our results indicated that these treatment differences (banded vs. broadcast chemical site preparation, without or with tip moth control) did not result in significant differences in average $\mathrm{DBH}$, average height and dominant height, survival, stand basal area, and total volume at age 2. A previous study also found that there was no significant difference between banded and broadcast site preparation herbicide applications in terms of average DBH, average height, stand basal area, and volume at ages 5 and 8 years (Zhao et al. 2008a). From the third growing season, intensive management regimes had additional complete competition control and repeated fertilization treatments compared to operational regime. As a result, intensive management consistently and significantly increased average DBH, height, stand basal area, and volume from age 4. Several studies show that complete and/or sustained vegetation control and repeated fertilization significantly increase longterm pine production (Martin and Shiver 2002; Nilsson and Allen 2003; Zhao et al. 2008b; Zhao et al. 2009a, b).

The management intensity and planting density interaction was only statistically significant for average DBH. For the intensive regime, the effect of planting density on average DBH became significant age 4, while for the operational regime the planting density effect became significant at age 6 . Thereafter, there was a clear trend of declining average DBHs as the planting density increased for both management intensities. Differences in average DBH among lower densities (741, 1,483, 2,224, and 2,965 trees/ha) were significant, while there was no significant difference between higher densities (3,706 and 4,448 trees/ha). The added fertilization and weed control with intensive management accelerated stand development and resulted in larger differences in average DBH among 

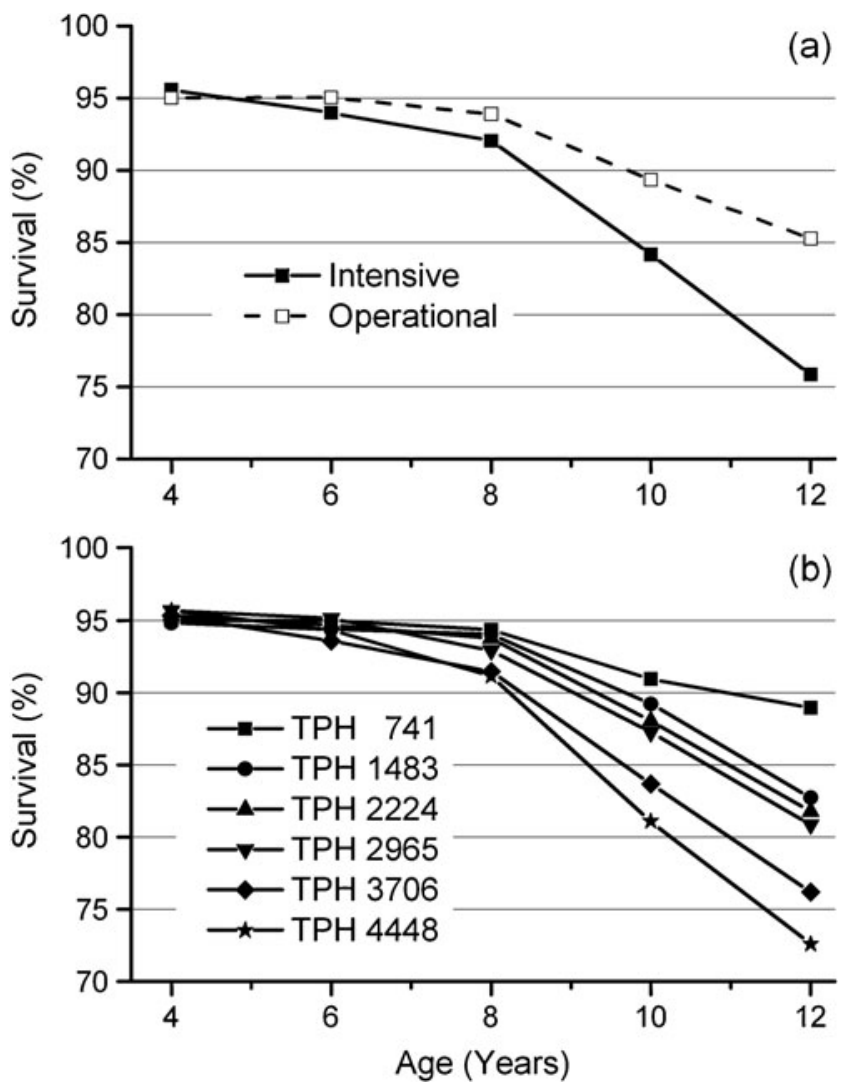

Fig. 5 Management intensity (a) and planting density (b) effects on stand survival of loblolly pine plantations planting densities. There was less difference in average DBH between the intensively managed and operational plots at higher densities than at lower densities. Several loblolly pine spacing studies with different ranges of planting densities have shown that stand average $\mathrm{DBH}$ at wider spacing was consistently greater than at closer spacing (Pienaar and Shiver 1993; Harms et al. 2000; Sharma et al. 2002). With planting densities that ranged from 247 to 2,471 trees/ha, Pienaar and Shiver (1993) observed that planting density significantly influenced the average DBH of loblolly pine in the Georgia Piedmont after age 8 years. Harms et al. (2000) reported that differences in spacing (730-3,086 trees/ha) in average DBH were evident 4 years after planting. Carlson et al. (2009) also reported that the differences in average DBH between 897 and 1,794 trees/ha initial densities became significant after age 5 . The detectable reduction in average $\mathrm{DBH}$ due to increasing planting density implies the onset of intraspecific competition. Our study, along with other spacing studies, suggested that intraspecific competition at early ages or before canopy closure could be significant.

It is believed that planting density has little effect on the height growth for many commercially valuable species (e.g., Clutter et al. 1983). Some studies support this statement (Pienaar and Shiver 1984; Harms et al. 1994, 2000). Several spacing trials, however, have identified an influence of stand density on height growth for loblolly

Table 5 Pairwise comparisons for mean basal area and mean volume per hectare among planting densities and between management regimes by age

\begin{tabular}{|c|c|c|c|c|c|c|c|}
\hline & & Age 2 & Age 4 & Age 6 & Age 8 & Age 10 & Age 12 \\
\hline \multicolumn{8}{|l|}{ Basal area } \\
\hline \multirow[t]{2}{*}{ Management } & Intensive & $\mathrm{a}$ & $\mathrm{a}$ & $\mathrm{a}$ & $\mathrm{a}$ & $\mathrm{a}$ & $\mathrm{a}$ \\
\hline & Operational & $\mathrm{a}$ & $\mathrm{b}$ & $\mathrm{b}$ & $\mathrm{b}$ & $\mathrm{b}$ & $\mathrm{b}$ \\
\hline \multirow[t]{6}{*}{ Planting density } & 741 & $\mathrm{a}$ & $\mathrm{a}$ & $\mathrm{a}$ & $\mathrm{a}$ & $\mathrm{a}$ & $\mathrm{a}$ \\
\hline & 1,483 & $\mathrm{a}$ & $\mathrm{b}$ & $\mathrm{b}$ & $\mathrm{b}$ & $\mathrm{b}$ & $\mathrm{b}$ \\
\hline & 2,224 & $\mathrm{a}$ & $\mathrm{bc}$ & $\mathrm{bc}$ & $\mathrm{bc}$ & $\mathrm{bc}$ & $\mathrm{bc}$ \\
\hline & 2,965 & $\mathrm{a}$ & $\mathrm{cd}$ & $\mathrm{c}$ & $\mathrm{c}$ & d & d \\
\hline & 3,706 & $\mathrm{a}$ & $\mathrm{cd}$ & $\mathrm{cd}$ & $\mathrm{c}$ & $\mathrm{cd}$ & $\mathrm{cd}$ \\
\hline & 4,448 & $\mathrm{a}$ & $\mathrm{d}$ & $\mathrm{d}$ & d & d & d \\
\hline \multicolumn{8}{|l|}{ Total volume } \\
\hline \multirow[t]{2}{*}{ Management } & Intensive & $\mathrm{a}$ & $\mathrm{a}$ & $\mathrm{a}$ & $\mathrm{a}$ & $\mathrm{a}$ & $\mathrm{a}$ \\
\hline & Operational & $\mathrm{a}$ & $\mathrm{b}$ & $\mathrm{b}$ & $\mathrm{b}$ & $\mathrm{b}$ & $\mathrm{b}$ \\
\hline \multirow[t]{6}{*}{ Planting density } & 741 & a & $\mathrm{a}$ & a & a & a & a \\
\hline & 1,483 & $\mathrm{a}$ & $\mathrm{a}$ & $a b$ & $\mathrm{~b}$ & $\mathrm{~b}$ & $\mathrm{~b}$ \\
\hline & 2,224 & $\mathrm{a}$ & $\mathrm{a}$ & $\mathrm{bc}$ & $\mathrm{b}$ & $\mathrm{bc}$ & $\mathrm{bc}$ \\
\hline & 2,965 & $\mathrm{a}$ & $\mathrm{a}$ & $\mathrm{bc}$ & $\mathrm{bc}$ & $\mathrm{cd}$ & $\mathrm{c}$ \\
\hline & 3,706 & $\mathrm{a}$ & $\mathrm{a}$ & $\mathrm{bc}$ & $\mathrm{bc}$ & bcd & $\mathrm{bc}$ \\
\hline & 4,448 & $\mathrm{a}$ & $\mathrm{a}$ & $\mathrm{c}$ & $\mathrm{c}$ & $\mathrm{d}$ & $\mathrm{c}$ \\
\hline
\end{tabular}

Within ages, the same letter among planting densities or the same letter between management regimes indicates no significant difference $(p=0.05)$ 
pine (Pienaar and Shiver 1993; MacFarlane et al. 2000; Sharma et al. 2002; Zhao et al. 2008b). Pienaar and Shiver (1993) found significant differences in average heights at age 8 with a planting density range of $247-2,471$ trees/ha but no significant difference among planting densities ranging from 988 to 2,471 trees/ha. Carlson et al. (2009) reported no significant differences in height at age 9 between 897 and 1,794 trees/ha planting densities. With a wide range of planting densities (747-6,719 trees/ha), MacFarlane et al. (2000) found a highly significant negative correlation between planting density and height from ages 14 and 16. Our study also includes a wide range of planting densities (741-4,448 trees/ha). We found significant differences between the low densities (741 and 2,224 trees/ha) and high densities (3,706 and 4,448 trees/ha) in both average height and average dominant height as early as 8 years after planting. Although no significant differences in heights were observed among planting densities within the 741-2,224 trees/ha range or within the 2,965-4,448 trees/ha planting density range, there was a clear trend of declining average height and average dominant height as the planting densities increased for both intensive and operational management regimes. Initial density may not significantly affect height growth in the density range of 1,000-2,000 trees/ha which typifies current loblolly pine
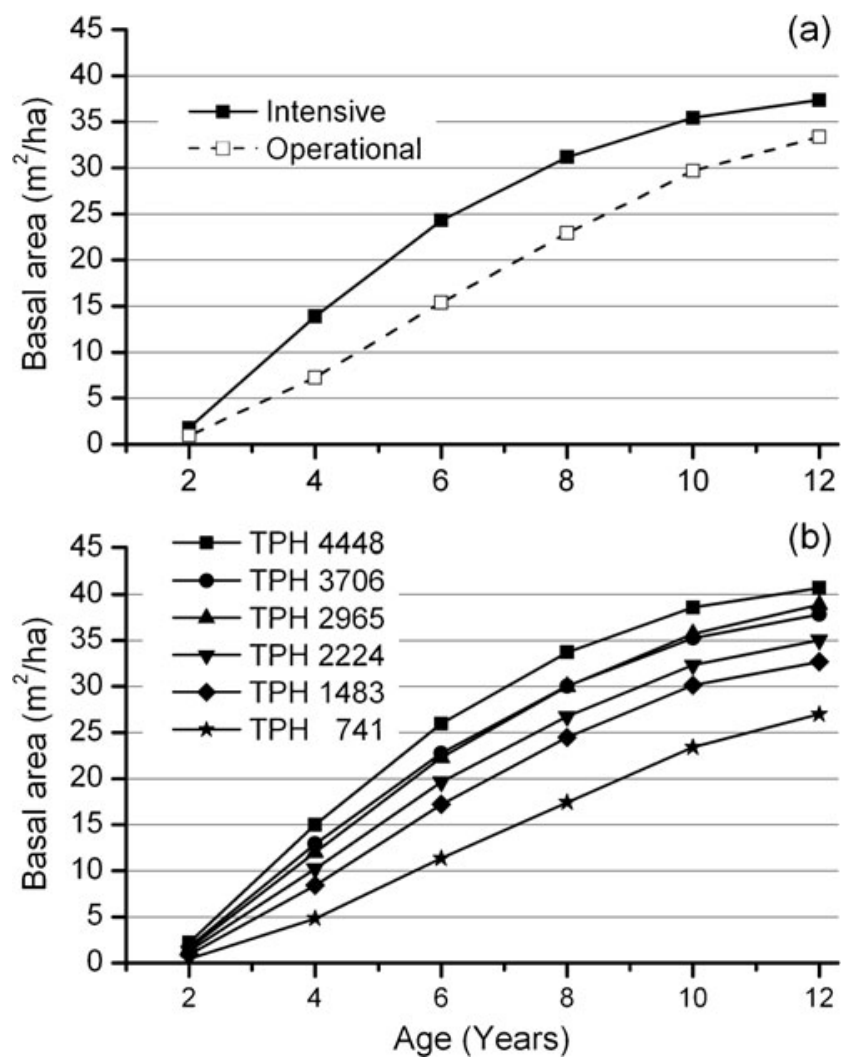

Fig. 6 Management intensity (a) and planting density (b) effects on stand basal area of loblolly pine plantations planting densities in the Lower Coastal Plain. When studies include extreme densities outside the normal range, however, height differences due to initial density are significant after a specific age.

In this study, management intensity did not significantly impact the survival rate until 12 years after planting. Complete vegetation control and repeated fertilization in intensive management enhanced pine growth, thus accelerating the process of density-related mortality. As a result, at age 12 the intensively managed plots underwent stronger density-related competition and had more mortality. Self-thinning began earlier and trees died in greater numbers in high planting densities (3,706 and 4,448 trees/ha), with the effects of planting densities on mortality becoming significant 10 years after planting. By age 12, all plots were exhibiting apparent density-related, intra-specific competition as evidenced by mortality. However, a significant difference in mortality only occurred between the more extreme densities. Similar results have been reported in other spacing trials (Carlson et al. 2009; Land et al. 2004). Carlson et al. (2009) reported no significant difference between planting densities of 897 and 1,794 trees/ha in loblolly pine mortality through age 9 . Land et al. (2004) did not find significant differences in the survival among the planting densities of $1,077,1,682$, and 4,305 trees/ha prior to age 9 .
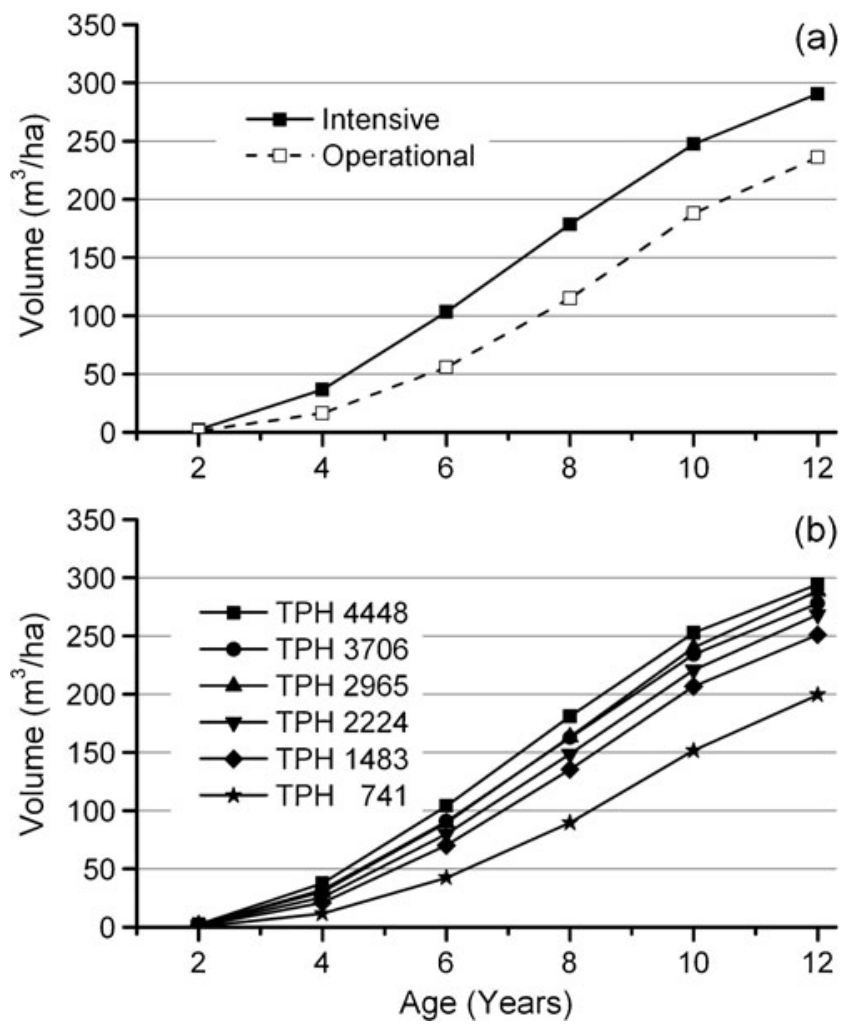

Fig. 7 Management intensity (a) and planting density (b) effects on total stem volume of loblolly pine plantations

\section{a)}

(b) 
The effects of initial density were significant on stand basal area and total stem volume from ages 4 and 6 , respectively. Management intensity significantly affected both stand basal area and total stem volume from age 4 . Basal area and volume yields increased with increasing planting density, with the greatest incremental increase from the 1,483 trees/ha density as compared to the 741 trees/ha density. By ages 10 and 12 years, there were no significant differences in basal area and volume for planting densities above 2,224 trees/ha. Stand basal area growth has begun to slow down, especially on plots with high density, intensive management, or a combination of both. Total stem volume growth continued to increase during the assessment period.

The results demonstrate that both management intensity and planting density significantly affect loblolly pine productivity in the Lower Coastal Plain and, with the exception of DBH growth, there is no significant interaction between management intensity and planting density for key stand attributes of mean height, mean dominant height, survival, basal area per hectare, and volume per hectare. This general lack of interaction indicates that, through age 12, management intensity effects are consistent across a broad range of planting densities and planting density effects are consistent across the operational and intensive regimes described in this study. This suggests that the effects of management regimes and of planting density, as described for this study and from other research for loblolly pine in the Lower Coastal Plain, can generally be considered additive in nature. Forest managers can expect consistent responses to cultural regimes across a range of densities and consistent responses to planting densities across a range of cultural regimes through age 12 . The selection of optimum cultural regime and planting density combinations will be highly dependent on economic factors such as markets for different products, e.g., biomass for bioenergy, pulpwood, and sawtimber, and the ability to integrate planting density and plantation establishment and young stand cultural regimes with desired harvest, either thinning or final harvests.

Acknowledgements The authors thank M. Harrison and J. Rheney for their invaluable assistance with the data and two anonymous reviewers for their helpful comments on an earlier version of this paper. This study was sponsored by the Plantation Management Research Cooperative at the University of Georgia's Warnell School of Forestry and Natural Resources.

\section{References}

Borders BE, Will RE, Markewitz D, Clark A, Hendrick R, Teskey RO, Zhang Y (2004) Effects of complete competition control and annual fertilization on stem growth and canopy relations for a chronosequence of loblolly pine plantations in the lower coastal plain of Georgia. For Ecol Manage 192:21-37

Carlson CA, Fox TR, Creighton J, Dougherty PM, Johnson JR (2009) Nine-year growth responses to planting density manipulation and repeated early fertilization in a loblolly pine stand in the Virginia Piedmont. South J Appl For 33(3):109-114

Clutter JL, Fortson JC, Pienaar LV, Brister GH, Bailey RL (1983) Timber management: a quantitative approach. Wiley, New York, p 333

Harms WR, DeBell DS, Whitesell CD (1994) Stand and tree characteristics and stockability in Pinus taeda plantations in Hawaii and South Carolina. Can J For Res 24(3):511-521

Harms WR, Whitesell CD, DeBell DS (2000) Growth and development of loblolly pine in a spacing trial planted in Hawaii. For Ecol Manage 126(1):13-24

Land SB Jr, Roberts SD, Duzan HW Jr (2004) Genetic and spacing effects on loblolly pine plantation development through age 17. In: Connor Kristina F (ed) Proceedings of the 12th Biennial Southern Silvicultural Research Conference. Gen. Tech. Rep. SRS-71. US For. Serv. Southern Res. Stn, Asheville, NC, pp 413-419

Littell RC, Milliken GA, Stroup WW, Wolfinger RD, Schabenberger $\mathrm{O}$ (2006) SAS ${ }^{\circledR}$ for mixed models, 2nd edn. SAS Institute, Cary, $\mathrm{NC}$

MacFarlane DW, Green EJ, Burkhart HE (2000) Population density influences assessment and application of site index. Can J For Res 30(9):1472-1475

Martin TA, Jokela EJ (2004) Stand development and production dynamics of loblolly pine under a range of cultural treatments in north-central Florida, USA. For Ecol Manage 192:39-58

Martin SM, Shiver BD (2002) Impacts of vegetation control, genetic improvement and their interaction on loblolly pine growth in the southern United States-age 12 results. South J Appl For 26 (1):37-42

Miller JH, Zutter BR, Zedaker SH, Edwards MB, Newbold RA (2003) Growth and yield relative to competition for loblolly pine plantation to midrotation - a southeastern United States regional study. South J Appl For 27(4):237-252

Nilsson U, Allen HL (2003) Short- and long-term effects of site preparation, fertilization and vegetation control on growth and stand development of planted loblolly pine. For Ecol Manage 175:367-337

Pienaar LV, Shiver BD (1984) The effect of planting density on dominant height in unthinned slash pine plantations. For Sci 30 (4):1059-1066

Pienaar LV, Shiver BD (1993) Early results from an old-field loblolly pine spacing study in the Georgia Piedmont with competition control. South J Appl For 17(4):193-196

Pienaar LV, Burgan T, Rheney JW (1987) Stem volume, taper and weight equations for site-prepared loblolly pine plantations. PMRC Res. Pap. 1987-1, University of Georgia, School of Forest Resources, $11 \mathrm{pp}$

Quicke H, Glover G, Glover R (1999) Loblolly pine growth response to herbaceous vegetation control at different planting densities. Can J For Res 29:960-967

Sharma M, Burkhart HE, Amateis RL (2002) Modeling the effect of density on the growth of loblolly pine trees. South J Appl For 26 (3): $124-133$

Shiver BD, Martin SW (2002) Twelve-year results of a loblolly pine site preparation study in the piedmont and upper coastal plain of South Carolina, Georgia, and Alabama. South J Appl For 26 (1):32-36

Zhao D, Kane M, Borders BE, Harrison M (2008a) Pine growth response to different site-preparation methods with or without post-plant herbaceous weed control on north Florida's lower coastal plain. For Ecol Manage 225:2512-2523 
Zhao D, Kane M, Harrison M, (2008b) SAGS culture/density study: results through age 10. PMRC Tech. Rep. 2008-3, University of Georgia, Warnell School of Forestry and Natural Resources, $33 \mathrm{pp}$

Zhao D, Kane M, Borders BE, Harrison M, Rheney JW (2009a) Site preparation and competing vegetation control affect loblolly pine long-term productivity in the southern Piedmont/upper coastal plain of the United States. Ann For Sci $66: 705$
Zhao D, Kane M, Borders BE, Harrison M (2009b) Long-term effects of site preparation treatments, complete competition control, and repeated fertilization on growth of slash pine plantations in the flatwoods of the southeastern United States. For Sci 55(5):403410

Zutter BR, Miller JH (1998) Eleventh-year response of loblolly pine and competing vegetation to woody and herbaceous plant control on a Georgia flatwoods site. South J Appl For 22 (2):88-95 